\title{
Learning to Detain Asylum Seekers and the Growth of Mass Immigration Detention in the United States
}

\author{
Smita Ghosh and Mary Hoopes
}

\begin{abstract}
Drawing upon an analysis of congressional records and media coverage from 1981 to 1996, this article examines the growth of mass immigration detention. It traces an important shift during this period: while detention began as an ad hoc executive initiative that was received with skepticism by the legislature, Congress was ultimately responsible for entrenching the system over objections from the agency. As we reveal, a critical component of this evolution was a transformation in Congress's perception of asylum seekers. While lawmakers initially decried their detention, they later branded them as dangerous. Lawmakers began describing asylum seekers as criminals or agents of infectious diseases in order to justify their detention, which then cleared the way for the mass detention of arriving migrants more broadly. Our analysis suggests that they may have emphasized the dangerousness of asylum seekers to resolve the dissonance between their theoretical commitments to asylum and their hesitance to welcome newcomers. In addition to this distinctive form of cognitive dissonance, we discuss a number of other implications of our research, including the ways in which the new penology framework figured into the changing discourse about detaining asylum seekers.
\end{abstract}

\section{INTRODUCTION}

In the past four decades, the number of noncitizens detained by the United States has grown at a staggering rate. In 1985, the government detained an average of 3,380 noncitizens on a given day; ${ }^{1}$ in June 2019, this number exceeded 52,000 (Jefferis 2019). Immigration imprisonment was "reborn" in 1981 in response to the unexpected migration of more than 150,000 Cubans and Haitians (Simon 1998, 579). However, the detention of noncitizens was otherwise relatively rare during this period. In stark contrast to today, immigration authorities did not routinely detain noncitizens after a final deportation order was entered, even when the reason for deportation was a criminal

Smita Ghosh is a Research Fellow and Adjunct Professor of Law, Georgetown University Law Center, Washington, DC, United Statessg1387@georgetown.edu

Mary Hoopes is a Director of Research, Berkeley Judicial Institute, University of California Berkeley School of Law, United States mhoopes@berkeley.edu

The authors would like to thank Jonathan Simon, Taeku Lee, Leti Volpp, Irene Bloemraad, Kevin Quinn, Sarah Barringer Gordon, and Sophia Lee for their comments on this manuscript. We are grateful to Margaret Taylor for generously sharing archival resources, and to Emma Clark and Samantha Ho for their outstanding research assistance.

1. Oversight Hearing: Immigration and Naturalization Service, before the Committee on the Judiciary, Subcommittee on Immigration, Refugees, and International Law, 99th Cong. (1986), 111. 
conviction (Taylor 2005, 3). For those whom it did detain, a bond hearing was available, and an administrative precedent established a presumption of release (3).

While modern-day immigration detention began with President Ronald Reagan's 1981 policy, it was the legislature that ultimately entrenched the system of mass confinement. It began with a series of laws that targeted noncitizens with criminal convictions. In the Anti-Drug Abuse Act of 1986, Congress authorized immigration officials to seek a detainer for anyone arrested for a controlled substance offense. ${ }^{2}$ Two years later, Congress required that the Immigration and Naturalization Service (INS) take custody of any noncitizen convicted of an "aggravated felony," creating an entirely new population of detainees (García Hernández 2014, 1337, 1370). In 1996, Congress changed immigrant detention even more drastically, passing the Antiterrorism and Effective Death Penalty Act of 1996 (AEDPA) and the Illegal Immigration Reform and Immigrant Responsibility Act of 1996 (IIRIRA). ${ }^{3}$ In addition to mandating the detention of a wide variety of noncitizens with criminal convictions, these acts contained stringent detention provisions for arriving migrants, including asylum seekers. The detention of noncitizens grew dramatically, including a "sharp increase" in the detention of asylum seekers (García Hernández 2014, 1370; Acer and Byrne 2017, 373).

How did the INS's targeted, crisis-specific detention efforts of the early 1980s develop into a broad, legislatively mandated detention scheme? Scholars have not yet undertaken a comprehensive historical examination of the period between 1981, when President Reagan announced his policy of detaining Haitian asylum seekers, and 1996, when Congress passed its far-reaching detention mandate. In particular, they have not explored how Congress evolved from initially criticizing the executive's detention practice to instituting a broad scheme of mandatory detention over the INS's objections. Our analysis reveals that a critical component of this evolution was a transformation in the perception of asylum seekers. Until the early 1990s, legislators focused their detention efforts on noncitizens with criminal convictions and continued to express concern that these policies could infringe upon the rights of asylum seekers. As we demonstrate below, this changed in the early 1990s as a variety of dynamics converged to create an alleged asylum crisis. These included, for example, a rise in asylumseeking and undocumented immigration, the recasting of unauthorized migration as a crime, the end of the Cold War, the creation of an asylum crisis in the media, and a concurrent asylum crisis in Europe (Loescher and Scanlan 1986, 69; Hedges 1993, A6; Hamlin 2015, 332).

Congressional discourse about asylum changed dramatically. Lawmakers began depicting asylum seekers as either potential criminals or agents of infectious diseases. This new discourse came to justify the systemic detention of asylum seekers and cleared the way for the mass detention of immigrants more broadly. Just as policy makers became more comfortable detaining in the criminal context, they also learned to detain and exclude potential refugees. Once the label of criminality had been extended to asylum seekers, lawmakers were motivated to enact reforms that would limit the rights of

2. Anti-Drug Abuse Act, Pub. L. No. 99-570, 100 Stat. 3207 (1986).

3. Antiterrorism and Effective Death Penalty Act of 1996, Pub. L. No. 104-132, 110 Stat. 1214 (1996); Illegal Immigration Reform and Immigrant Responsibility Act (IIRIRA) of 1996, Pub. L. No. 104-208, 110 Stat. 3009 (1996). 
arriving asylum seekers and increase their incarceration, guaranteeing that they were more likely to see the inside of a prison than the inside of a courtroom. This shift in Congress's perception of asylum seekers has been largely absent from scholarship on the origins of immigration detention. With some significant exceptions (Martin 1995; Schuck and Williams 1999; Taylor 2003, 2005), many scholars treat the executive and Congress as monolithic in their support of immigration detention.

As we argue in this article, the two branches in fact changed positions over this period. Treating the executive and Congress as though they were uniformly pursuing the same goal of detention obscures a more complex interplay between the two institutions in the period leading to the mass detention of immigrants. In addition, most accounts of detention begin with the passage of the AEDPA and the IIRIRA in 1996. As we argue, the preceding fifteen years, which we divide into three "eras," are essential to understanding how immigration detention became normalized and institutionalized within the United States. We present a number of implications that follow from this study. First, a comprehensive analysis of more than five thousand pages of legislative history and government records from 1981-96, supplemented by more than one hundred newspaper and magazine articles, reveals how Congress extended the label of criminality to asylum seekers, who became a subtype of another legislative preoccupation, the so-called "criminal alien." 4 This discursive shift grew from the association between asylum seekers and terrorism-which is itself rooted in racialized conceptions of dangerousness - and the changing meaning of asylum in the years after the Cold War. As this shift occurred, lawmakers increasingly turned to mandatory detention policies that precluded individualized determinations of risk. We illuminate how many of the same processes that drove the mass incarceration movement were at work within the immigration detention movement as well.

Second, our analysis reveals a distinctive form of cognitive dissonance at work within the transformation of asylum seekers. In the early 1990s, lawmakers and the public wrestled with the dissonance between the humanitarian commitment to protecting refugees, on the one hand, and the fears provoked by the realities of this commitment, on the other. In studies of the post-9/11 period, scholars have emphasized that asylum seekers were marked by their "otherness" and became implicitly associated with the dangerousness of the regimes they fled (Malloch and Stanley 2005, 43; Welch and Schuster 2005, 344). As our analysis reveals, lawmakers perceived asylum seekers as being dangerous and risky much earlier. In the early 1990s, legislators and the public branded asylum seekers as criminals (or "Typhoid Marys"), avoiding the dissonance between proposed reforms and their humanitarian commitment to refugees. In this way, lawmakers constructed a new, deviant class through a process that Seyla Benhabib (2012) has referred to as "othering."

Third, a long-described relationship between procedural interventions and substantive severity within criminal law also contributed to the detention of asylum seekers. In the criminal law context, William Stuntz $(1997,5)$ argues that legislators reacted to expansions of procedural protections from the courts by expanding the scope

4. While we recognize that the term "criminal alien" has a dehumanizing effect, we use it within this article because a central component of our analysis is the rhetoric used to describe noncitizens over this period. 
of liability, increasing punishments, and underfunding criminal defense. As we describe below, lawmakers responded to expanded procedural protections for asylum seekers in a similar way, by expanding opportunities for their exclusion and detention.

Finally, we propose a relationship between detention and expedited removal, a streamlined exclusion process initiated in the same 1996 legislation. Scholars have long decried expedited removal, both because it dramatically restricts individual rights and because it fails to "protect society against potentially dangerous accretions of government power" (Kanstroom 2018, 1326). We find the roots of this controversial program in the convergence of two very different legislative concerns, one about reducing detention and another about increasing immigration enforcement. As we show below, screening mechanisms that were once implemented in order to release asylum seekers from detention were later incorporated into the expedited removal system and divorced from their decarceral roots.

\section{EXISTING LITERATURE ON THE GROWTH OF DETENTION}

We build upon a growing literature that examines the convergence of mass incarceration and immigration detention (Chacón 2012; McLeod 2012; Stumpf 2014). As we detail below, scholars have rooted the rise of immigrant detention in many of the same dynamics that spurred the development of mass incarceration. Criminologist Jonathon Simon (1998) was the first to place the detention of noncitizens within the larger history of the mass incarceration movement. Legal scholars Mary Bosworth and Emma Kaufman $(2011,431)$ have also argued that noncitizens became "the next and newest 'enemy' in an American war on crime." Political scientist Marie Gottschalk (2014, 215-17) shows that immigrants became "important new drivers of the carceral state." Sociologist Patrisia Macías-Rojas $(2018,2)$ emphasizes that Democrats as well as Republicans recast unauthorized migration as a crime, showing that the crime politics of both parties in the early 1990s played an undeniable and understudied role in shaping the IIRIRA's criminal provisions. Drawing on the notion of institutional path dependence, Cesar Cuauhtémoc García Hernández (2014, 1498) argues that, once immigration officials embraced the political rhetoric of migrant criminality, they became locked in a pattern of expanding imprisonment. None of these scholars, though, assess the specific intersection between asylum seekers and the war on crime, nor do they take an institutional perspective to understand how this transformation occurred.

Scholars have also connected the rise of immigration detention in the 1990s to theories of crime policy during the same period. Several have applied Jonathan Simon and Malcolm Feeley's (2003) "new penology" framework to the growth of immigration detention, tracing the development of group-based approaches to immigrant dangerousness. Simon and Feeley argue that the 1990s-era expansions of crime-based deportation grounds represent a blend of new penology and a premodernist fear of the foreigner (99). Teresa Miller $(2003,646)$ demonstrates that criminal aliens were understood as dangerous classes and managed by an actuarial model of justice. Michael Welch (1996, 181; 2002, 152) invokes the new penology to explain the rise of detention in the 1990s, suggesting that officials viewed noncitizens as "dangerous groups" worthy of detention. In the UK context, 
Bosworth and Guild $(2008,710)$ explore how crime control has influenced the governance of migration and argue that the dispassionate, administrative handling of noncitizens resonates with the new penology's actuarial approach.

Several scholars have observed that immigration detention, like criminal incarceration, is rooted in racial hostility and has become a racialized tool of social control (Welch 1996, 178; García Hernández 2019, 11). In the past several years, scholars from several disciplines have centralized the experience of asylum seekers in the 1980s-especially those from Haiti-in the history of the detention system. Sociologist Jeffrey Kahn $(2019,15)$ argues that the treatment of Haitian asylum seekers grew from a "cauldron of anxiety" that included racism, the rise of the neoliberal carceral state, and legal activism on the part of asylum advocates. For historian Carl Lindskoog $(2018,8)$, the government's treatment of Haitians in the 1980s and 1990s demonstrates the "convergence" of immigration and the "carceral state" and the persistence of racism in the decades after the civil rights movement. Geographers Jenna Loyd and Alison Mountz $(2018,5)$ root contemporary detention in the Carter and Reagan administrations' Cold War-inflected response to the arrival of Haitian and Cuban asylum seekers in the 1970s and 1980s.

Like these scholars, we view the years preceding the AEDPA and the IIRIRA as essential to understanding the laws' detention provisions and how detaining asylum seekers became routine. We add to the scholarship on the legislative history of the IIRIRA's detention provisions. Peter Schuck and John Williams (1999, 422-50) demonstrate that state and local governments, increasingly frustrated by the costs associated with incarcerating noncitizens, convinced Congress to enact mandatory detention provisions. David Martin $(1999,167)$, writing as a legal academic and the former General Counsel of the INS, describes how the INS opposed the expedited removal provisions in the IIRIRA. Margaret Taylor (2005, 2-9) has explained that Congress went from neglecting the INS's inability to remove noncitizens with criminal convictions in the 1980 s to hastily writing broad detention mandates into the 1996 legislation, over the objections of the agency. We draw upon this work in our review of debates about immigration detention between 1981 and 1996. We examine how immigration detention evolved from an ad hoc executive initiative into a far-reaching system of confinement mandated by the legislature. As we reveal, the legislative preoccupation with immigrants with criminal convictions gave way to an association between criminality and asylum seekers, grounded in a rhetoric of risk in which asylum seekers were presumptively dangerous.

We expand upon scholarship that tracks the use of deterrence as a justification for asylum policy. Scholars have described "a regime of deterrence" in asylum law that fully took hold after the 1994 congressional election (Hamlin 2012, 47; Loyd and Mountz 2018). In a detailed account of legislative efforts to enact asylum reforms in the 1990s, Philip Schrag $(2000,5,94)$ demonstrates that the expedited removal provisions of the IIRIRA followed an "asylum crisis" that was animated by at least three factors: acts of terrorism attributed to asylum seekers in 1993, growing concern about the backlog of asylum cases, and extensive press accounts of alleged abuse of the asylum system. We build upon the work of Hamlin and Schrag by tracing the evolution of congressional attitudes toward the detention of asylum seekers specifically. Most notably, we understand the changing perception of asylum seekers in the broader context of the legislative preoccupation with the criminal alien, exploring a relationship that most scholars have ignored. 


\section{DATA AND METHODS}

This article conducts a careful historical analysis of the fifteen-year period that culminated in legislation that would formalize the mass detention of immigrants. It draws on multiple sources of data, including congressional hearings, case law, federal archives, and print media. To more fully assess Congress's treatment of immigration detention, we compiled data from Proquest Congressional, focusing on all congressional hearings from 1981 through 1996. Using a search framework that identified any variation of the word "detain" in proximity to variations of the words "asylum," "alien," or "migrant," we reviewed more than five thousand pages of legislative history, which included over eighty congressional hearings, after excluding search results unrelated to immigration policy. This included, for example, committee reports, hearing transcripts, and congressional communications with the executive branch. The logic of this inquiry was inductive and exploratory, as we sought to allow findings to develop through the frequent and dominant themes that emerged (Webley 2010, 942). This permitted us to examine how legislative perceptions evolved, and we analyzed these records to identify changes in congressional reactions to immigrant detention. For example, we paid careful attention to questions from legislators to agency officials concerning the funding of detention centers, allegations from constituents concerning detention, and lawmakers' discussion of the propriety of detention generally.

These sources offer a window into the public politics of immigrant detention and reveal how lawmakers have understood the INS's use of detention. While the membership of Congress changed during the study period, we noticed trends even in individual lawmakers' approach to detention. For example, we compared Romano Mazzoli (D-KY)'s 1982 statement that he "opposed long-term detention for aliens" ${ }^{5}$ and his 1994 statement of concern about noncitizens with convictions being "paroled to the streets" rather than remaining in custody, in addition to assessing statements of various members and committees across the period. ${ }^{6}$

We supplemented this analysis of congressional records with (1) a review of print media sources for their treatment of detention, refugees, and asylum seekers; (2) a review of archival materials concerning the Asylum Pre-Screening Officer (APSO) program; and (3) records from the Reagan and Clinton libraries. We created a database of media coverage of immigration detention across a large range of sources from 1981 to 1996. We conducted a detailed review of this coverage and, following Rebecca Hamlin $(2012,39)$, were able to identify points of tension and critical moments during this history. In addition to tracking critical moments, we focused on editorials because official editorials are likely to reflect the institutional preferences of the newspapers and may help track general attitudes (Chomsky 1999). A close reading of the more than one hundred articles in this database helped us to construct a timeline of the major

5. Hearing on Detention of Aliens in Bureau of Prison Facilities, before the Subcommittee on Courts, Civil Liberties, and the Administration of Justice of the Committee on the Judiciary, House of Representatives, 97th Cong. (2nd sess.) (1982), 249

6. Hearing on Detention of Aliens (1982), 255; Criminal Aliens, H.R. 723, H.R. 1067, H.R. 1279, H.R. 1459, H.R. 1496, H.R. 2041, H.R. 2438, H.R. 2730, H.R. 2993, H.R. 3302, H.R. 3320 (Title IV), H.R. 3860 (Titles II, V, VI), H.R. 3872, and H. Con. Res. 47, before the Committee on the Judiciary, Subcomm. on Immigration, Refugees, and International Law, 103rd Cong. (1994), 190. 
events in detention and enabled us to locate crucial changes in the discourse around asylum seekers.

\section{ANALYSIS}

The evolution of mass detention between 1981 and 1996 can be roughly divided into three "eras" that each reflect a different dynamic between the executive and the legislature. These boundaries are approximate, of course, as they reflect a complex and dynamic interplay between the branches, but they help demonstrate the evolution of attitudes toward detention. The first era begins in 1981 when Congress resisted the executive's detention policy, expressing particular concern about detaining asylum seekers. A shift began to take place in the second era, beginning in the late 1980s as the legislative preoccupation with the so-called "criminal alien" began. While members of Congress expressed support for the detention of noncitizens with criminal convictions, they largely resisted the detention of asylum seekers. Finally, in the third era, beginning in 1993, several domestic and foreign policy considerations converged to create an "asylum crisis" that was marked by an abrupt shift in legislative discourse. Legislators began to describe asylum seekers as "Typhoid Marys" and criminals who sought to abuse the system. They viewed detention as necessary to deter this abuse. Once lawmakers were comfortable with detaining asylum seekers, the system of mass detention quickly followed. Legislators engaged in a frenzied effort to reform immigration law and hastily enacted the IIRIRA's broad mandatory detention policies over the objection of immigration officials.

\section{The First Era: The Executive's Push for the Power to Detain}

Following the arrival of over 150,000 Cubans and Haitians to Florida between 1980 and 1981, the Reagan administration reinvented immigration imprisonment. This followed a hiatus of nearly twenty-seven years, during which the government employed an official policy of releasing migrants on parole in most circumstances (Simon 1998, 579). Under Reagan's policy, anyone who arrived without proper travel documents would be detained pending a determination of their status (Welch 1996, 170). This detention was not entirely new, as Haitians in Florida facing deportation in the 1970s had been imprisoned "on a sporadic basis" (Loescher and Scanlan 1986, 193). The Carter administration had also used detention for some of the nearly one hundred thousand Cubans who had landed along the Florida coast in a boatlift from the Cuban port city of Mariel (the "Mariel Cubans") and who could not be resettled to sponsors (Simon 1998, 579; Lindskoog 2018, 45; Loyd and Mountz 2018, 56-63). Because the INS had not used detention systematically in the past, the Reagan administration lacked the infrastructure to do so under and began detaining individuals in overcrowded prisons and jails (Macías-Rojas 2018, 4).

The Reagan administration defended the 1981 detention policy to Congress by trumpeting it as a deterrent to future immigration crises. As INS Commissioner Alan Nelson told Congress in 1982, "the detention policy ... puts pressure on people 
not to come unless they have a legal right to be here." Similarly, the attorney general told Congress that the country had "lost control of [its] borders" and would, without detention, "crumble under the burden of overwhelming numbers." 8 The Reagan administration was aware of the "politically explosive" nature of refugee issues (Loyd and Mountz 2018, 66), especially in Florida, where the governor and congressional delegation often reminded the administration of the "adverse [e]ffects" of the refugee population on the local community (Task Force on Immigration and Refugee Policy 1981).

Detention was a crucial component of the executive's immigration policy agenda. The Reagan administration included in its proposed immigration reform bill a provision that would "make clear" the attorney general's authority to detain migrants - even indefinitely- "so there can be no doubt regarding the power of the United States to protect the public by detaining .... all of the arriving aliens during an emergency, as circumstances warrant." 9 The administration asserted that its "broad authority to detain" was clear, explaining that the "language of this bill [wa]s merely intended ... to preclude the judiciary from second-guessing the Executive Branch's decisions." Senators from Florida, commenting that the arrival of Cuban and Haitian migrants to South Florida had wrought "tragedy, fear, and crime," introduced the president's proposal in the Senate in 1982 and 1983. The bill failed in committee, where Senator Alan Simpson (R-WY), expressed concern about overbroad executive power (Schmults 1984,1$){ }^{10}$

In addition to disapproving of the emergency powers bill, members of Congress voiced their opposition to the executive's use of detention. On May 21, 1982, fifty-five representatives, mostly Democrats, wrote a letter to the attorney general protesting the "indefinite imprisonment" of Haitians as "costly[,] inefficient," and offensive to "our historic commitment [to] political asylum." 11 At oversight hearings in 1982, representatives Hamilton Fish (R-NY) and Mazzoli (D-KY) pressed the INS commissioner about whether long-term detention should really "be the mission of the Immigration Service." 12

Lawmakers also expressed their dissatisfaction with detention in discussions about appropriations. In 1981, Congress removed $\$ 45$ million from the INS's budget, $\$ 35$ million of which had been intended for constructing an additional detention center. ${ }^{13}$ Most members of Congress explained the decision as a cost-effective way to reduce government spending. To them, constructing a new detention facility was especially unwarranted. In a hearing before the Appropriations Subcommittee, Representative Adam Smith (D-IA) asked if a "permanent facility" was "necessary," given the government's use of temporary detention

7. Committee on the Judiciary, Immigration Reform and Control Act of 1982, H.R. Rep. No. 97-890 (1982), 408.

8. Joint Hearing on Administration's Proposals on Immigration and Refugee Policy, before the Committee on the Judiciary, Subcomm. on Immigration, Refugees, and International Law and U.S. Senate, 97th Cong. (1981), 6,75 .

9. Hearing on Immigration Emergency Powers, before Subcommittee on Immigration, Refugees, and International Law and U.S. Senate, 97th Cong. (1982), 26.

10. Hearing on Immigration Emergency Powers, 2, 27, 30.

11. Hearing on Detention of Aliens (1982), 255.

12. Oversight Hearing, 86, 94.

13. Committee on Appropriations, Conference Report to Accompany H.J. Res. 357, H.R. Rep. No. 97-352 (1981), 28. 
spaces and the president's new interdiction policy. ${ }^{14}$ Other lawmakers asked if the money could go to other INS efforts instead. ${ }^{15}$ When the Department of Justice again asked for the funding in supplemental appropriations, Congress, once again, pushed back. Some of the pushback came from Florida legislators, who were most opposed to detention centers in their districts rather than detention as a policy, but some lawmakers expressed opposition to immigration detention itself. ${ }^{16}$ Writing to the House Subcommittee on Courts, Representative Robert Kastenmeier (D-WI) urged members to "carefully examine" the Department of Justice's request. ${ }^{17}$ Detention was inappropriate, he argued, because it interfered with migrants' right to counsel, prevented family reunification, and already cost the taxpayers approximately $\$ 37$ million annually. Representative Mazzoli, chairman of the House Immigration Subcommittee, said that the detention of Haitians "reflected adversely on our traditional history of humane treatment of aliens and refugees." ${ }^{18}$ Several months later, and after Kastenmeier's committee held a lengthy hearing on the detention policy, Congress granted the Department of Justice only $\$ 17$ million, half of the requested amount, for the construction of an immigration detention facility.

During this era, the legislature was relatively sympathetic to asylum seekers and introduced a number of measures to influence the executive's asylum procedure and policy. In the early 1980s, each house approved legislation that would have provided more education to immigration officers about human rights abuses and more training about interviewing asylum applicants (Loescher and Scanlan 1986, 196). These measures were not ultimately passed because of the failure to reach an agreement on immigration reform legislation. In 1983, both houses attached a nonbinding resolution to a foreign aid appropriations bill urging President Reagan to grant extended voluntary departure status to asylum seekers from El Salvador (196). The administration ultimately ignored this, however, and was similarly unmoved by a large "sanctuary movement" by church leaders that hid Salvadoran and Guatemalan asylum seekers in churches and parishioner homes (196).

While recent arrivals triggered discourse of crime, deviance, and disease within the media, many members of Congress drew a distinction between asylum seeking and criminality in this era. Immigration and health agencies described Haitians and Mariel Cubans as threatening, particularly because of their alleged association with sexually transmitted diseases and homosexuality, but legislators still opposed their detention (Hufker et al. 1990; Paik 2016, 85-113). In June 1982, Simpson (R-WY) and Mazzoli, chairmen of the immigration subcommittees in the Senate and House, respectively, visited the Krome Avenue detention camp in Miami. "Having visited these Haitians in their detention facilities," they wrote in a joint press release, "we know they are not criminals and that our policy should not be to detain them in such facilities." .

14. Departments of Commerce, Justice, and State, the Judiciary, and Related Agencies Appropriations for 1982 Part 11: Budget Amendments and Deferrals for FY82, before the Committee on Appropriations, 97th Cong. (1981), 91-92.

15. Immigration Reform, before the Committee on the Judiciary, Subcommittee on Immigration, Refugees, and International Law, 97th Cong., 1st sess. (1981), 834.

16. Central American Asylum Seekers, Before the Committee on the Judiciary, Subcommittee on Immigration, Refugees, and International Law, 101st Cong. (1989), 25.

17. Hearing on Detention of Aliens (1982), 228.

18. Hearing on Detention of Aliens (1982), 228, 248-49. 
Similarly, the House Committee on the Judiciary reported that it was "deeply troubled by the long-term detention of Haitian nationals undergoing asylum hearings," particularly because these detainees were "not criminals." 19

Prior scholarship has recognized that the reception of asylum seekers was sharply divided along racial lines. This was apparent in the treatment of asylum seekers fleeing Communist regimes, as Southeast Asians were not met with the welcome reception experienced by those from the Soviet Union (Loescher and Scanlan 1986, 117). A "double standard" began as early as the 1960s that permitted Cubans to enter the United States with few restrictions, while Haitian "boat people" were rarely granted asylum (69). Despite the rapid deterioration of human rights within the Haitian government, State Department officials maintained that Haitian asylum seekers were economic migrants who were not entitled to asylum. ${ }^{20}$ Haitians did not benefit from the political power of the Cuban enclaves in the United States and were further marginalized by the "perception that they were poor, black, and difficult to resettle" (Loescher and Scanlan 1986, 178).

The "action and leadership" of detained Haitians brought this unequal treatment to the public's eye (Lindskoog 2018, 7). In addition, "siege litigation" on their behalf produced telling court decisions (Kahn 2019, 23). In a 1979 class action lawsuit, challenging the denial of more than four thousand Haitian asylum applications, the presiding federal judge described the "first substantial flight of black refugees from a repressive regime to this country." Noting that most Cubans seeking political asylum prior to the Mariel boatlift were successful, and none of the more than four thousand Haitian applicants had been granted, the court observed that "no greater disparity can be imagined." 21

Allegations of discrimination fueled legislators' concerns about the executive's detention policy. In their letter of protest to the attorney general, members of Congress-mostly Democrats—referenced the advocates' legal victories. ${ }^{22}$ The Congressional Black Caucus, along with many interest and humanitarian groups, complained that the asylum process prevented the entrance of Haitians while serving as a mere formality when applied to Cubans. ${ }^{23}$ The welcome reception of Cuban immigrants changed dramatically after the arrival of the Mariel Cubans. They were increasingly labeled as "criminals, sociopaths, homosexuals, and troublemakers" (Loescher and Scanlan 1986, 217), in part due to the perception that Fidel Castro had expelled Cubans who had been previously institutionalized in Cuba, or the "dregs of society," to provoke American authorities (183).

Congress continued to express concern about the INS's use of detention through the mid-1980s. In an oversight hearing in 1986, lawmakers expressed a number of concerns about the executive's detention practices. They focused, in particular, on the construction of a new detention center in Oakdale, Louisiana, which was designed to house

19. Committee on Appropriations, Conference Report, 52.

20. Caribbean Migration, before the Committee on the Judiciary, Subcommittee on Immigration, Refugees, and International Law and U.S. Senate, 96th Cong. (1980), 207.

21. Haitian Refugee Center v. Civiletti, 503 F. Supp. 442 (S.D. Fla. 1980), 451.

22. Hearing on Detention of Aliens (1982), 255.

23. Cuban/Haitian Adjustment, before the Committee on the Judiciary, Subcomm. on Immigration, Refugees, and International Law and U.S. Senate, 99th Cong. (1984), 163-64. 
long-term immigration detainees and free bed space for more short-term detention at the border. Chairman Mazzoli pressed Assistant Commissioner Hugh Brien about whether detention was the best use of the INS's limited assets and whether the INS should be in the business of detaining people at all. ${ }^{24}$ Chairman Mazzoli was in fact so opposed to the idea of long-term immigration detention that he sought legislation limiting its use. In July 1986, the House Immigration Subcommittee considered an amendment, introduced by Mazzoli, that would have required the attorney general to release detained migrants on bond unless they posed a danger to the community or were likely to abscond. ${ }^{25}$ As the Judiciary Committee explained in an accompanying report, this provision grew from their concern about the detention of asylum seekers:

[T] he Committee has noted with growing concern the increased incidence of detention on the whole and the increased use of long-term detention of aliens who have exercised their right to a proceeding on their claim to entry, particularly asylum. The Committee strongly disagrees with any attempted use [of] detention as a method of deterring the exercise of rights granted under the immigration law. ${ }^{26}$

The provision, entitled "a clarification of the temporary nature of detention," would have returned the executive's detention practices to those of the pre-1981 era, in which the INS did not routinely detain arriving noncitizens.

The success of this bill in the House exemplifies Congress's concern about the long-term detention of asylum seekers in the first era. The Immigration Subcommittee and Judiciary Committee of the House all passed Mazzoli's provision. The bill also passed the Democratically controlled House by voice vote, although it failed in the Republican-controlled Senate. In the mid-1980s, the House's immigration priorities often clashed with those of the Reagan administration, but the fact that members of Congress identified detention as an issue of concern is still striking and suggestive of the strength of congressional opposition to the detention policy at the time (Kaplowitz 2018, 644-50). Later in the first era, lawmakers expressed concerns about immigration detention by inquiring into the prolonged detention of Mariel Cubans. Most Mariel Cubans were released on parole after screening, but, in 1987, over 3,500 remained in federal custody (Gibson 1988). The detainees staged a series of prison riots in November of that year, successfully drawing attention to their incarceration (Loyd and Mountz 2018, 238). While media portrayals of the Cubans often reflected their "deviance" or social undesirability immediately following the Mariel boatlift (Hufker et al. 1990, 333), the press was also very critical of the lengthy detention that some of them faced. As the New York Times reported, a "clamor" was rising over the detention of Mariel Cubans (Volsky 1987). Even before the riots, the editorial boards of

24. Oversight Hearing, 20, 79.

25. Administration of the Immigration and Nationality Laws, H.R. 4823, H.R. 4444 and H.R. 2184, before the Committee on the Judiciary, Subcommittee on Immigration, Refugees, and International Law, 99th Cong. (1986), 42.

26. Committee on the Judiciary, Immigration and Nationality Amendments of 1986, H.R. Rep. No. 99-907 (1986), 33. 
several newspapers argued against their "cruel and unusual" treatment (New York Times 1986; Washington Post 1987).

At congressional hearings about the riots, lawmakers expressed concern about the possibility of indefinite detention (Welch 2002, 97). ${ }^{27}$ Representative John Lewis (DGA) objected after visiting the Atlanta Penitentiary that the conditions were "truly appalling" and that the detainees had been indefinitely detained with no chance of judicial review or due process. ${ }^{28}$ In July 1988, the House Immigration Subcommittee considered several provisions that would have limited the detention of excludable aliens and provided counsel for those detainees who were financially unable to obtain adequate representation. Representative Kastenmeier noted that these provisions had bipartisan support, emphasizing: "That we as Americans could have permitted the indefinite and often inhumane incarceration of fellow human beings for so long is nothing short of a tragedy." 29

At the end of the first era, legislators from both parties were more likely to question the executive about the overuse of immigration detention than to demand its increase. Newspapers had the same tendency, reporting on accusations of bias in the detention process (Johnson 1982), sharing sympathetic portrayals of asylum seekers in detention (Morrison 1987), and criticizing what one paper called the "department of detention" (New York Times 1982). However, this was a time of transition. Even Chairman Mazzoli, who sponsored the bill that would limit long-term immigration detention, expressed mixed feelings. He voiced concern that, if noncitizens were not detained, they could rapidly establish roots in the community by marrying, having children, and buying property. In his view, these were the very factors noncitizens might use to "throw themselves on the mercy of the immigration court and say: it is going to be a terrible hardship for me to leave." ${ }^{30}$ As detailed below, these concerns would prevail in the coming years.

\section{The Second Era: The Rise of the "Criminal Alien"}

While the legislature continued to express concern about the detention of asylum seekers during the second era, it rapidly developed a preoccupation with what it called the criminal alien. Crime had been a central issue in US politics for nearly two decades, and the war on drugs was in full force during this era (Simon 2007, 262), but this concern had not yet moved into the immigration arena (Macías-Rojas 2018, 2). In the mid1980s, however, what Margaret Taylor $(2005,4)$ has characterized as a "something of an insider's secret" began to capture the legislature's attention: that the INS lacked the necessary infrastructure to remove many noncitizens with criminal convictions, so that "[d]eportable criminals slipped through the cracks at every point in the removal

27. Mariel Cuban Detainees: Events Preceding and Following the November 1987 Riots, before the Committee on the Judiciary, Subcommittee on Courts, Civil Liberties, and the Administration of Justice, 100th Cong. (1988).

28. Mariel Cuban Detainees: Events Preceding, 5.

29. Mariel Cuban Detainees, H.R. 4330 and H.R. 4349, before the Committee on the Judiciary, Subcommittee on Immigration, Refugees, and International Law, 100th Cong. (1988), 13.

30. Administration of the Immigration and Nationality Laws, 249. 
process." Lawmakers from Florida, New York, and California - the states with the most noncitizens and, therefore, the most "criminal aliens"-were especially vocal (Schuck and Williams 1999, 379). Indeed, Senator Alfonse D'Amato (D-NY), citing concerns about crime in New York City, made the first congressional inquiry into the INS's approach to "criminal aliens" (425).

In May 1986, at D'Amato's request, the Senate Committee on Appropriations ordered the attorney general to provide the committee with a detailed strategy for investigating and deporting noncitizens with criminal convictions (Schuck and Williams 1999, 425). Hearings revealed the extent of the INS's inaction. Lawmakers castigated the service for detaining so few criminal aliens. ${ }^{31}$ In October, Congress passed the AntiDrug Abuse Act of 1986, which established pilot cooperation programs between the INS and local law enforcement and required immigration authorities to respond to local requests regarding the immigration status of people arrested on drug charges. ${ }^{32}$ As awareness of the INS's inability to remove noncitizens grew, lawmakers began to consider mandatory detention as a solution for those with criminal convictions. In March 1987, a Senate Subcommittee held a public hearing on the INS's inability to effectively deport so-called criminal aliens. ${ }^{33}$ Both state and local officials testified in support of a no-bond policy for convicted felons. In 1988, Senator Lawton Chiles (D-FL) introduced unsuccessful amendments to the INS that laid the groundwork for subsequent mandatory detention legislation. ${ }^{34}$

At this point, lawmakers still drew a sharp line between asylum seekers and criminal aliens, seeking only to detain the latter. Indeed, as Senator Chiles explained, his proposed bill drew a distinction between an illegal alien, who may be entitled to certain rights (such as the asylum seeker), and "an illegal alien felon," whom he described as "another creature entirely." 35 While Chiles's bill was ultimately unsuccessful, very similar language found its way into the Anti-Drug Abuse Act of 1988, which mandated detention without the possibility of bond for noncitizens convicted of aggravated felonies. ${ }^{36}$ Less than a year later, in the Immigration Act of 1990, Congress expanded the aggravated felony definition, increasing the number of noncitizens subject to mandatory detention. ${ }^{37}$ Critically, Congress passed these provisions despite the INS's very limited detention capacity, which rendered it incapable of fulfilling the statute's mandates.

While the legislative preoccupation with the so-called criminal alien deepened, a number of changes weakened support for asylum in the legislature. The 1980s were marked by two distinctive challenges in immigration: a dramatic increase in undocumented immigration generally and the arrival of unprecedented numbers of "first asylum" refugees after the passage of the Refugee Act of 1980 (Tichenor 1994, 333). ${ }^{38}$

31. Emerging Criminal Groups, before the Committee on Governmental Affairs, Permanent Subcommittee on Investigations, 99th Cong. (1986), 268, 294.

32. 8 U.S.C. $\S 1357(d)$ (1994).

33. Illegal Alien Felons: A Federal Responsibility, before the Committee on Governmental Affairs, Subcommittee on Federal Spending, Budget, and Accounting, 100th Cong. (1987).

34. Implementation of the Immigration Reform and Control Act: S. 972, S. 973, S. 974 and S. 975, before the Committee on the Judiciary, Subcomm. on Immigration, Refugees, and International Law, 100th Cong. (1988).

35. Implementation of the Immigration Reform, 22.

36. Anti-Drug Abuse Act of 1988, Pub. L. 100-690, 102 Stat. 4181 (1998).

37. Immigration Act of 1990, Pub. L. 101-649, section 501, 104 Stat. 4978 (1990). 
Attitudes toward asylum seekers had also soured in Europe; by the 1980s, European countries were "overwhelmed" by asylum applications, and headlines described "an asylum crisis" (Boswell 2007, 541). Before the 1980s, refugee admissions had been politicized to the benefit of applicants from communist countries and the Middle East (Loescher and Scanlan 1986; Yarnold 1990, 528). The Refugee Act of 1980 was intended to usher in an entirely new era of asylum law in which the definition of refugee was depoliticized and there was no longer a bias in favor of "hostile-state" applicants (Yarnold 1990, 529). However, in the years after its passage, the INS continued to deny asylum to large numbers of Central Americans fleeing El Salvador and Guatemala.

In 1988, the number of Central Americans fleeing conflict to the United States rapidly increased, putting greater pressure on the asylum system. That year, immigration officials in South Texas went from receiving 407 asylum applications in a year to receiving more than thirty thousand in six months, all from Central America. In March 1989, the House Immigration Subcommittee held a hearing on the detention of Central American asylum seekers and their impact on local communities. This marked a turning point when congressional sympathy for asylum seekers began to erode. Lawmakers from Texas and Florida, whose state populations had grown with the addition of recent asylum seekers, spoke of the resulting "burdensome impact" on the communities they represented. Representative John Bryant (D-TX) worried that the Refugee Act "was written to take care of situations where a sailor jumps off a ship or a ballerina leaves the ballet troupe, rather than to accommodate a mass migration of thousands of people from the south." 39

While there was a marked change in lawmakers' willingness to invoke the burdens of asylum, legislators were not yet advocating the detention of asylum seekers. Legislators from Texas urged the federal government to develop a uniform response to immigration crises and relieve the burden on local communities, but they did not ask for asylum seekers to be detained. Instead, they urged immigration officials to close "loopholes" in the asylum system and worried that the Reagan administration had created the crisis by promising asylum to Nicaraguans fleeing the country's socialist government. Congressman Dante Fascell (D-FL), for example, emphasized the "very serious impact" of asylum seekers on the state of Florida, but argued that detention was not a good use of the Service's resources and could not be "reasonably maintain[ed] as a policy." 40 INS Commissioner Nelson responded that detention had served as a successful deterrent in Florida and South Texas and pledged to continue. ${ }^{41}$

Meanwhile, the problem of the criminal alien continued to gain traction within Congress and the media. Following widespread reporting on the inability of the INS to remove aliens with criminal convictions, the House Immigration Subcommittee convened another hearing on the issue in November 1989. As Chairman Mazzoli framed the issue in his opening remarks, the "deportation capacity and performance" of the INS was "woefully inadequate." In several studies, the General Accounting Office (GAO) had concluded that criminal aliens who should have been deported

38. Refugee Act of 1980, Pub, L. 96-212, 94 Stat. 102 (1980).

39. Central American Asylum Seekers, 16, 28, 192.

40. Central American Asylum Seekers, 16, 31, 68.

41. Immigration and Naturalization Service Budget and the Naturalization Process, before the Committee on the Judiciary, Subcommittee on Immigration, Refugees, and International Law, 100th Cong. (1989), 49-50. 
had instead remained and then committed additional crimes. Both lawmakers and the press depicted noncitizens as "prone" to drug-related offenses and "violent kinds of crime." 42

The INS's inability to deal with the "criminal alien problem" was once again at issue in legislative hearings in 1992, when Congress met to discuss the INS's budget and its general operations. The detention policy was a particular point of contention. Legislators urged the agency to "deploy" its detention resources and "get criminal illegal aliens out of our communities." While legislators were insistent on detention, they rejected the INS's request for more funding, protesting that previous budget increases had not led to improvements. ${ }^{43}$ Furthermore, as Schuck and Williams (1999, 436-42) demonstrate, the INS suffered from a poor relationship with the Department of Justice during this period, which had issued scathing audits of several INS programs and often diverted the service's appropriation requests (440-42).

\section{The Third Era: A New Perception of Asylum Seekers, Clearing the Way for Mass Detention of Immigrants}

Over the next three years, unauthorized migration was recast as a crime issue, rather than as a predominantly economic problem, in the popular imagination (Macías-Rojas 2018, 3). During this period, the categories of the "illegal alien" and "criminal alien" began to be conflated, a blurring that continues to the present day (McLeod 2012, 165). Newspapers throughout the country connected immigrants to rising crime rates, often by focusing on specific incidents of criminal behaviour by immigrants or by relaying the opinions of community members or officials (Harris and Gruenewald 2020). Furthermore, after a major recession beginning in 1990, immigration became a "hot-button" political issue, and nativist organizations, including the prominent Federation for Immigration Reform (FAIR), gained political power (Skelton 1993; Chavez 2001, 134-38). As political scientists have argued, anti-immigrant sentiment reached a post-Second World War pinnacle in the mid-1990s, due to economic insecurity, a large and sustained immigrant flow (including an increase in undocumented immigration), and social and ethnic differences between the new arrivals and native majority (Muller 1997, 105). This new restrictionism resulted in California's passage of Proposition 187, which sought to deny most public services and education to undocumented immigrants and their children, and the proliferation of "English only" laws (Diamond 1996, 156).

Patrisia Macías-Rojas $(2018,6)$ emphasizes that both political parties recast unauthorized migration as a crime issue in the early 1990s. In June 1993, Senator Dianne Feinstein published an op-ed pledging to take a tougher stance on unauthorized immigration and urging President Bill Clinton to do the same. Rather than "having our taxpayers underwrite the prison costs" for noncitizens convicted of crimes, she alleged, the

42. Criminal Aliens, H.R. 3333, before the Committee on the Judiciary, Subcommittee on Immigration, Refugees, and International Law, 101st Cong. (1989), 1, 2, 36.

43. Immigration and Naturalization Service's General Operations and Fiscal Year 1993 Budget, before the Committee on the Judiciary, Subcommittee on Immigration, Refugees, and International Law, 102nd Cong. (1992), 3, 68, 100. 
federal government should deport them to their home countries for imprisonment (Feinstein 1993). At the same time, other Democrats began to propose bills addressing noncitizens with criminal convictions (Macías-Rojas 2018, 6). For example, Representative Chuck Schumer (D-NY) introduced a bill authorizing the use of closed military bases for detaining noncitizens with convictions. Macías-Rojas concludes that these bills were not ultimately enacted in part because immigration was not yet sufficiently entangled with crime in the public imagination (7). As we argue below, the accompanying shift in the perception of asylum seekers was essential to this transformation.

In 1993, an "asylum crisis" was born in the media and quickly took hold of the legislature. In February of that year, just one month after a Pakistani asylum seeker killed two people in the parking lot of a Central Intelligence Agency building in Virginia, a car bomb exploded in the parking garage of the World Trade Center, killing six people (Schrag 2000, 39). One of those responsible for the World Trade Center bombings, Ramzi Yousef, had claimed asylum after entering the country with a fake passport (39). Those supporting more restrictive immigration policies quickly seized upon this to characterize asylum as an easy way for criminals to enter the country. In a segment of 60 Minutes that was later introduced in Congress, a representative from FAIR, the leading anti-immigration lobbying group (41), explained that "if you get to the US, you say 'political asylum,' and that's it. That's your ticket in. You get a free ride. And you can stay indefinitely." 44 While newspapers reported critiques of this approach (New York Times 1993c; Leiden 1993), they also portrayed asylum as a "worldwide Siren's call to foreigners" (Clines 1993) and a loophole that could be exploited by noncitizens seeking to "remain in the country indefinitely" (Ostrow 1994).

Asylum seekers were now associated with criminality implicitly by virtue of being undocumented and, explicitly, as a result of terrorist events. In the summer of 1993, over 60 percent of Americans said that they favored decreased immigration, even from asylum seekers (Christian Science Monitor 1993). Many career officials in the INS echoed this restrictionism in well-publicized statements. William Slattery, director of the INS's New York office, warned the New York Times that the asylum system was "broken" and that "[t]he third world has packed its bags and it's moving" (New York Times 1993a). Administration officials tested the practice of detention when the Golden Venture, a ship containing thousands of asylum seekers from China, ran aground off Long Island in the summer of 1993 (New York Times 1993b). The administration was committed to detaining most of the passengers while they resolved their asylum cases, some of which lasted almost four years (Lake et al. 1996, 2; Dugger 1997). At the same time, the population of arriving Haitian asylum seekers grew dramatically after a 1991 coup, leading the Clinton administration to pursue a variety of tactics-off-shore detention, interdiction, and military invasion-to prevent what Clinton called "the next wave of refugees at our door" (Paik 2016, 99).

Underlying the discourse about the asylum crisis were several changes in the political meaning of asylum seeking in the early 1990s. First, the number of asylum seekers had grown. While the United States had received about five thousand asylum

44. Asylum and Inspections Reform: H.R. 1153, H.R. 1355, and H.R. 1679, before the Committee on the Judiciary, Subcommittee on Immigration, Refugees, and International Law, 103d Cong. (1993), 51. 
applications in 1980, this number had grown to more than one hundred thousand by 1993. ${ }^{45}$ Second, the end of the Cold War and the collapse of the Soviet Union had redefined asylum law. Most asylum seekers before the late 1980s were fleeing Communist countries, and they offered lawmakers a "powerful ideological symbol of the superiority of Western societies" (Boswell 2007, 540). Without the "Cold War frame," as Rebecca Hamlin $(2015,333)$ writes, asylum was "no longer insulated from the domestic politics of cost-saving and border control." Rather, the costs of asylum were thrown into sharp relief, especially as the racial makeup of asylum seekers continued to change.

Congress moved quickly to respond to the public pressure created by the media frenzy. As Philip Schrag $(2000,68)$ summarizes, "hearings proliferated on what was suddenly being portrayed as an asylum crisis." Lawmakers convened a hearing to focus upon asylum seekers who arrived by plane to New York and were released because of the INS's lack of detention space. The hearing reveals a dramatic shift in lawmakers' portrayal of asylum seekers. Chairman Mazzoli opened the hearing with the following statement:

The asylum system is sick. The asylum system needs attention in the very worst way. ... Thousands upon thousands of persons are entering the United States illegally, without papers, or in some cases, with fraudulent papers. Some enter for the benign purpose of finding a better life, and doing something with their talents. Some enter with nefarious schemes on their minds and terrorist impulses, some of which are given vent. Some of these people are walking Typhoid Marys-but in this case, it is not typhoid, but HIV, or it is infectious tuberculosis.

As Mazzoli's statement reveals, the language of disease and danger, which some executive officials had used to describe Haitian and Cuban asylum seekers for years, had entered the discourse of congressional Democrats. Moreover, as the statement demonstrates, Mazzoli and his colleagues were less likely to talk about particular populations of asylum seekers, as they had in earlier eras, and more likely to group asylum seekers based on their immigration status alone. ${ }^{46}$

This way of speaking led Mazzoli to conclude that the asylum system was being manipulated with ease. A scan of the newspaper articles introduced at this hearing underscores Mazzoli's point: "A Dreadful Mess at the INS" and "Think the Rio Grande Is a Porous Border? Try New York's JFK, where anyone can enter through the magic of political asylum." Referencing the noncitizens implicated in the World Trade Center bombing and the 1993 murders, Mazzoli concluded that the asylum system was "deeply flawed" and afforded "laboriously extensive due process." 47 While Chairman Senator Ted Kennedy (D-MA) took a more measured tone than Chairman Mazzoli, he and other senators emphasized that the asylum system was being abused and that it was necessary to develop means of preventing it. For lawmakers, detention was essential to resolving the asylum crisis. Representative Xavier Becerra

45. Asylum and Inspections Reform, 305.

46. Asylum and Inspections Reform.

47. Asylum and Inspections Reform, 1, 2, 121. 
(D-CA) explained that detention would "send that real strong message to someone who thinks that they can come in here, make a claim for asylum [and] escape our purview." 48 For Representative Schumer, a detention center near John F. Kennedy Airport would "take care of the problem" of asylum fraud. Lawmakers considered the "Asylum Reform Act," which included amendments that would require the INS to detain anyone, even an asylum seeker, who was not "clearly and beyond a doubt" entitled to enter. ${ }^{49}$

By now, the tables had clearly turned: legislators from both parties were eager to detain broad swaths of people, while the INS countered that this approach was neither feasible nor effective. Representative Xavier Becerra (D-CA), for example, argued that detention had deterred unauthorized migration in Los Angeles and complained that he did "not hear enough from the INS saying that detention and increasing the detention facility capacity is a priority." ${ }^{50}$ Representative Schumer argued that the inadequate capacity of the INS's detention facilities, which had been detailed in several GAO reports, resulted in noncitizens being released into the public to commit another crime after serving their sentences (GAO 1992).${ }^{51}$ Representative Mazzoli explained that the INS's detention facilities had not been able to keep up with the growing numbers of deportable alien criminals, and there were "simply more felons than there are beds in the INS detention facilities." 52 While the INS had repeatedly asked for more detention space, it made clear that some of Congress's detention proposals went too far. Gene McNary, who led the INS in the Bush administration, testified that detaining everyone who entered with fraudulent papers would be a "budget-buster" and cost over a billion dollars. In addition, mandatory detention would result in the confinement of "many persons who ... have come to the United States in search of a better life."

Much like the media exposure of the INS's inability to remove the criminal alien pushed Congress to act, the problems of the asylum system also spurred pressure to quickly introduce reform measures (Martin 1995, 738; Schrag 2000, 68). Concerned by what it called the "highly publicized problem of asylum abuse" and the fact that "many in Congress would prefer to dispense with ... asylum completely" if it did not offer a reasonably harsh alternative, the Clinton administration proposed a set of reforms that would allow for "summary processing" of asylum claims (Coven 1993, 1). The administration's proposal, which Senator Kennedy introduced as Section 1333 in July 1993, included a broad form of expedited expulsion (Schrag 2000, 50). As David Martin (1995, 740) notes, only about 10 percent of asylum cases began in exclusion - rather than deportation-proceedings, but the 60 Minutes episode focused on asylum seekers at the border, so reform efforts began there (Schrag 2000, 44). The political prominence of the asylum crisis is apparent from the fact that the administration announced its summary exclusion legislation in a press conference with the president, vice president, and attorney general (44).

48. Terrorism, Asylum Issues, and U.S. Immigration Policy, S. 667, before the Committee on the Judiciary, Subcommittee on Immigration and Refugee Affairs, 103rd Cong. (1993), 36.

49. Immigration and Naturalization Service's General Operations (1992), 21, 36.

50. Immigration and Naturalization Service's General Operations (1992), 131.

51. Immigration and Naturalization Service's General Operations, before the Committee on the Judiciary, Subcommittee on Immigration, Refugees, and International Law, 103rd Cong. (1994).

52. Criminal Aliens (1994), 1.

53. Asylum and Inspections Reform, 140. 
Congress also continued to build the system of mass immigration incarceration. A 1992 GAO (1992, 1-7) report had concluded that detention was "impractical and costprohibitive" as a solution to the problem of "border security." As Margaret Taylor $(2005,7)$ argues, "the political gain to be had from cracking down on criminal aliens enticed Congress to ignore this reality." Both parties rushed to appear tough on crime, introducing a dizzying array of proposed amendments. As Taylor describes, "several decades of near-total neglect were followed by frenzied overreaction" by Congress (5). In a Senate Immigration Subcommittee hearing on terrorism and asylum, Senator Simpson noted that many of his colleagues had reversed course on detention. As he observed, "those who are recommending increased detention years ago were saying detention was a terrible thing, and that we should be very sparing" in the use of detention. ${ }^{54}$ In November 1993, the Senate Permanent Subcommittee on Investigations convened to review an investigation of the Alien Criminal Apprehensions Program, initiated by ranking minority member Bill Roth (R-DE). At the hearing, lawmakers lambasted the INS as toothless, urging that detention was the only way to ensure that the agency deported noncitizens with criminal convictions. Lawmakers considered whether to eliminate immigration officials' discretionary authority to release some noncitizens. Assistant Attorney General Sheila Anthony opposed the proposal, arguing that the "INS does not have sufficient resources to detain each and every criminal alien until removal can be effected." She defended the INS's policy of balancing flight risk and danger to the community and emphasized the Department of Justice's support for preserving the service's discretion to release noncitizens from detention. ${ }^{55}$

After the congressional election of 1994, which gave the Republican party a majority in both houses of Congress, immigration detention was further entrenched in Congress. By now, the legislature's answer to the problem of criminal aliens was clear: detention was necessary for the agency to effectuate their removal. As Representative Susan Molinari (R-NY) explained, "the most important thing we can do when we rewrite our immigration laws is to focus on improving, number one, detention, and second, deportation." 56 In a March 1995 hearing, Representative Lamar Smith (R-TX) stated that the "most effective way" to deport a noncitizen was to detain them until removal. Smith, who was then chairman of the Immigration Subcommittee, said that detention would "send a message that we

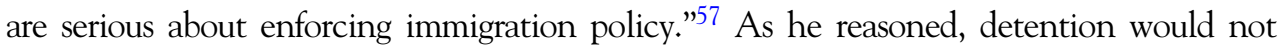
only remove noncitizens with criminal convictions but, as Margaret Taylor (1997b, 158) has argued, would also "restore credibility in the immigration enforcement system." Senators echoed these concerns in hearings later that year. Senator Feinstein pressed INS Commissioner Doris Meissner to look for detention spaces in the San Francisco Bay area. Chairman Smith said that without confinement, deportable noncitizens might "never [] be heard from again."

54. Terrorism, Asylum Issues, 25.

55. Criminal Aliens in the United States, before the Committee on Governmental Affairs, Permanent Subcommittee on Investigations, 103rd Cong. (1993), 100.

56. Members' Forum on Immigration, before the Committee on the Judiciary, Subcommittee on Immigration and Claims, 104th Cong. (1995), 39.

57. Removal of Criminal and Illegal Aliens, before the Committee on the Judiciary, Subcommittee on Immigration and Claims, 104th Cong. (1995), 2, 48.

58. Immigration and Naturalization Service Oversight: Reviewing the Status of Operations at the Immigration and Naturalization Service, before the Committee on the Judiciary, Subcommittee on Immigration, 104th Cong. (1996), 37. 
State and local governments continued to play a prominent role in advocating for increased detention, referencing the burden they bore in detaining so-called criminal aliens (Schuck and Williams 1999, 424). Several states began to seek compensation from the federal government for the costs associated with detaining noncitizens with criminal convictions (445). Lawton Chiles, who had become governor of Florida in 1991, announced plans to sue the government for failing to prevent illegal aliens from entering the state (446). Representatives, especially those from California and Florida, reported that the INS was unresponsive to their requests for the deportation of undocumented immigrants who were "pick[ed] up" by local police or "rounded up [in] drug sweeps." All these complaints focused on swift deportation and detention capability. Referencing the growth of noncitizen detainees in Santa Barbara jails, Representative Stephen Horn (R-CA), chairman of the House Subcommittee on Government Management, told his colleagues that "there must be a commitment, a streamlined, timely, and efficient INS enforcement program to ... deport illegal immigrants who have been arrested, detained and incarcerated in our local facilities."60

The sustained media attention to the INS's inability to remove noncitizens with criminal convictions, combined with pressure from legislators and local officials, pushed Congress to enact the AEDPA and the IIRIRA in 1996. As scholars have made clear, these laws marked a "seismic change" in the landscape of immigration detention (Taylor 1997a, 209). The laws greatly increased the situations in which immigration officials were required to confine noncitizens and also authorized state and local law enforcement officials to apprehend and detain immigrants on the government's behalf (García Hernández 2014, 1370). Furthermore, the law created "expedited removal" provisions for recent entrants, allowing for fast-track deportation of unauthorized migrants at the border unless they demonstrated a "credible fear" of persecution (Macías-Rojas 2018, 12). Both bills were controversial. Indeed, the IIRIRA barely passed and was revived by a last-minute agreement to incorporate amendments to the immigration statute to avoid a government shutdown (Martin 1999, 167; Taylor 2005, 8-9).

The 1996 legislation was enacted over the objections of the administration and with little regard to the institutional reality, particularly the agency's capacity to detain. The INS was "caught off guard" by these dramatic changes in the law (Schmitt 1996, B9; Taylor 2005, 8). While INS employees like Slattery had advocated for detention to deter asylum abuse, policy makers in the administration "strongly opposed" the IIRIRA's mandatory detention provisions (Fernandes 1998). According to members of the White House Domestic Policy Council, mandatory detention was "bad policy" and ignored the agency's institutional capacities (Fernandes 1998). Representatives of the INS explained as much in congressional testimony. ${ }^{61}$ In what Taylor $(2005,9)$ calls "a small concession to practical reality," Congress permitted the INS to delay implementation of mandatory detention for two years due to insufficient space.

59. Removal of Criminal and Illegal Aliens, before the Committee on the Judiciary, Subcommittee on Immigration and Claims, 104th Cong. (1996), 37, 65.

60. What Resources Should be Used to Control Illegal Immigration at the Border and within the Interior?, before the Committee on Government Reform and Oversight, Subcommittee on Government Management, Information, and Technology, 104th Cong. (1995), 114.

61. Criminal Aliens (1993), 100. 
The administration also opposed the provision of the law allowing for summary exclusion—or "expedited removal"—of recent arrivals. While the Clinton administration's 1993 asylum reform bill included a broad form of expedited exclusion, the administration reversed course in 1994, instead favoring a proposal that would have only allowed expedited removal in extraordinary immigration situations (Markus 1995, 7; Martin 1999, 164-67). David Martin $(1999,164)$ agrees that the summary exclusion components of the IIRIRA were "poorly conceived and poorly drafted" and describes agonizing over how to implement them because they broadly applied to all entrants without inspection rather than to just new arrivals.

\section{IMPLICATIONS}

\section{Cognitive Dissonance, the Rhetoric of Risk, and the "Othering" of Asylum Seekers}

Our analysis shows that asylum policy was transformed by congressional rhetoric that stigmatized asylum seekers as dangerous, risky criminals. Sociologists have long employed the term "moral panic" to describe the process by which a group comes to be defined as a threat to societal values and portrayed by the media in a highly stylized and stereotypical way (Garland 2008, 10). In addition to its use in explaining the growth of the criminal justice system (Garland 2008), scholars have also explored how a moral panic constructed the criminality of unauthorized immigrants (Bibler Coutin 2005, 14). Our research suggests that, in 1993, this moral panic took the form of an asylum crisis as a series of factors converged, including a rise in undocumented immigration and its recasting as a crime, increasing arrivals of asylum seekers, the end of the Cold War, a set of terrorist attacks, and a concurrent asylum crisis in Europe. Legislators began to understand incoming asylum seekers as dangerous classes, referring openly to asylum seekers as "Typhoid Marys" who might pass communicable diseases such as HIV onto citizens. Alternatively, they were depicted as criminals seeking to abuse the asylum system. ${ }^{62}$ Media portrayed the asylum system as a "loophole" for undeserving economic migrants or those with terrorist impulses. Asylum seekers were soon enveloped in a moral panic, and a new class of "deviants" was thus constructed (Foucault 1977). Indeed, the process of creating the "deviant" and labeling asylum seekers as deviants served to enhance social solidarity (Foucault 1977) and reinforce a particular form of collective identity (Benhabib 2012).

These conversations about the dangers of asylum seekers were mediated by a racial hierarchy. From the early 1980s, Haitians were affected by a racialized discourse of black criminality and accordingly perceived as a particularly "dangerous class" (Simon 1998, 594; Gibran Muhammad 2010, 7). Both Haitians and Cubans were perceived as nonwhite, but the INS was initially more willing to admit Cubans without restriction (Loescher and Scanlan 1986, 69). Soon after the arrival of the Mariel Cubans, as thousands came ashore daily, they too were stigmatized by the public as criminals and deviants (Simon 1998, 590-91). In the second and third eras, lawmakers focused less on

62. Asylum and Inspections Reform. 
single populations of asylum seekers and more on the threats of asylum seekers as a whole, but they maintained the sense of danger and contagion that had inflected popular perceptions of Haitians and Mariel Cubans, with the danger of terrorism layered upon particularly sexualized hazards raised by those populations.

In some ways, policy makers' approaches to asylum seekers represented the "new penology," a crime-policy discourse aimed at managing "dangerous groups" rather than rehabilitation (Simon and Feeley 1992). For lawmakers, branding asylum seekers as dangerous provided the system with a semblance of rationality that, just as in the mass incarceration movement, facilitated harsher treatment (454). In their eyes, immigrant detention facilitated deportation and border security, acting as a "social management instrument" rather than a site for punishment or reform (469). The new penology's "actuarial" approach also permeated the INS's approach to asylum seekers (453). In April 1992, in response to the "continued demand" of advocates, the agency created a corps of asylum pre-screening officers and piloted what it called the "APSO" program (Office of the General Counsel 1996, 1-3; Pistone 1999, 201-2; McNary 1992). In participating districts, APSO officers interviewed detained asylum seekers and recommended the release of those who had a "credible fear" of persecution or, in other words, were more likely to succeed in their claims and less likely to abscond (Office of the General Counsel 1996, 3). The INS's use of this screening device in detention centers, and Congress's adoption of the credible fear standard in expedited removal, discussed below, reflected a risk-based approach to managing asylum claims.

While lawmakers endorsed the INS's actuarial approach to assessing and detaining asylum seekers, they also used language that resembled the retributive, "vindictive penality" that, according to Simon and Feeley (2003, 108), operated alongside the new penology framework in immigration politics. Rather than employing an actuarial model to differentiate between levels of risk, lawmakers largely described asylum seekers as a single group, using the stigmatizing language discussed above. Legislators viewed the detention of asylum seekers as necessary to deter future abuse of the system, just as the mass incarceration movement shifted to a "culture of control" that emphasized deterrence over rehabilitation (Garland 2001).

In their study of asylum politics in the United Kingdom, Mary Bosworth and Mhairi Guild $(2008,712)$ complicate the distinction between actuarial and punitive approaches to the administration of justice and argue that, in the realm of immigration law, both approaches "work together" to create national identity. For Bosworth and Guild, the "criminalizing practices" of immigration law, whether inspired by actuarial logic or popular punitivism, help maintain the importance of citizenship "at the precise moment that national borders appear less and less relevant" (714). These practices neutralize the suffering of asylum seekers to maintain a clear distinction between citizens and noncitizens (714). Our study of American congressional discourse suggests a similar relationship between the ways that lawmakers described asylum seekers and their perceptions of American identity.

Allegra McLeod's (2012, 160-61) notion of "cognitive dissonance" is instructive in understanding the role of asylum seekers in the formation of national identity. McLeod identifies two forms of "cognitive dissonance" prevalent in immigration discourse: a racial dissonance, in which a norm of colorblindness stands in tension with the racial anxiety surrounding immigration, and an economic one, in which the public's 
reliance on immigrant labor conflicts with its unwillingness to extend associated economic privileges to immigrant workers (159). As McLeod argues, the category of the criminal alien relieves some of the dissonance by providing a discrete and identifiable group to be held responsible for the ills posed by immigration (166). Our analysis reveals another form of dissonance at work within the transformation of asylum seekers. During the "asylum crisis," lawmakers wrestled with the "dissonance" between the nation's commitment to providing protection to refugees and the fears provoked by the perceived threat of asylum seekers. Even today, asylum occupies a special place within immigration law because of its unique humanitarian aim, and it has enjoyed support even among those inclined to support more restrictive immigration policies (Martin 1995, 738). And, yet, as this history reveals, this commitment is quite fragile. As soon as the magnitude of people seeking refuge began to test it, and as their race, culture, or socioeconomic status made them more likely to be perceived as "the other," legislators soon began describing them in dramatically different ways.

We suggest that lawmakers may have emphasized the dangerousness of asylum seekers to resolve the dissonance between their theoretical commitment to asylum and their hesitance to welcome newcomers. In the early 1990s, the number of people seeking asylum increased dramatically. Furthermore, asylum lost the political significance it had during the Cold War, so that admitting asylum seekers was riskier. Finally, the new asylum seekers tended to be nonwhite, adding to the political costs of refugee admission. Rudolph Giuliani $(1992,811)$, writing when he was associate attorney general, admitted as much when defending the imprisonment of Haitians and Cubans. As he argued, the American political tolerance for immigration, and its "absorptive capacity," is "affected by a wide range of economic, cultural, and political considerations." Many scholars have posited that asylum law posed a threat of opening "floodgates" and have termed the resulting tendency to close the gates a "compassion fatigue" (Chavez 2001, 133). Otto Santa Ana $(2002,102)$ has described how the "individuality and humanity of the immigrants [we]re replaced with a frightening scenario of inundating surges of brown faces." We suggest that legislators resolved this compassion fatigue by branding asylum seekers as criminals (or "Typhoid Marys"), thereby adhering to the humanitarian commitment to refugees while adopting what Hamlin $(2015,334)$ has persuasively called a "regime of deterrence" in asylum law.

\section{The Relationship between Detention and Procedural Protections}

Scholars of criminal law have long described a relationship between procedural interventions and substantive severity. William Stuntz $(1997,5)$ argues that in the 1970s and 1980s legislators reacted to judicial expansions of procedural protections by expanding the scope of criminal liability, increasing punishments, and underfunding criminal justice efforts. In the immigration context, Jeffrey Kahn (2019) and A. Naomi Paik $(2016,8)$ report a similar tendency on the part of executive officials, who use extraterritorial enforcement and detention to avoid judicial decisions and the "ascension of rights" within the territory.

Our analysis reveals the same dynamic. During the 1980s, courts were less likely to invoke the plenary power doctrine and more willing to review immigration policy 
(Schuck 1992, 85). During this period, courts invalidated key INS policies and practices and expanded the procedural rights of noncitizens (Schuck and Williams 1999; Kahn 2019). Just as legislators expanded the scope of criminal liability in response to changes in criminal procedure, Congress continually expanded the scope of the aggravated felony definition, vastly increasing the number of noncitizens subject to removal. Additionally, Congress restricted the INS's discretion by mandating detention, much like Congress turned to mandatory minimum sentences in response to the perceived inadequacy of discretionary sentencing (Murakawa 2014). Finally, in what was perhaps the most dramatic pushback to the judicial expansion of procedural rights, Congress eliminated sentencing judges' ability to issue judicial recommendations against deportation (Schuck and Williams 1999, 438).

Legislators also reacted to the perceived expansion of asylum seekers' procedural protections by turning to detention. During the "asylum crisis" of the 1990s, legislators blamed procedural protections for abuse of the system. Chairman Mazzoli described a "sick" asylum system, plagued by rampant abuse enabled by "laboriously extensive due process." 63 The settlement in American Baptist Churches likely brought this issue to the fore, as it entitled Central American applicants who had entered before 1990 to entirely new asylum hearings (Schrag 2000, 31). ${ }^{64}$ Legislators reasoned that detention was necessary to deter abuse of the asylum system: in the wake of complaints about "asylum abuse" at airports, for example, Congress funded detention centers near the alleged abuse (Schrag 2000, 69). ${ }^{65}$ In addition, just as it had in the criminal alien context, Congress responded by streamlining asylum procedures and limiting access to judicial review, a subject to which we now turn.

\section{Detention and the Roots of Expedited Removal}

Our study also reveals a curious relationship between detention and the expedited removal provisions of the IIRIRA. Scholars have long decried expedited removal for restricting individual rights and failing to "protect society against potentially dangerous accretions of government power" (Kanstroom 2018, 1326). Our analysis locates the roots of this controversial program in the convergence of two very different legislative concerns, one about reducing detention and another about increasing immigration enforcement. During the asylum crisis of the 1990s, resistance to expedited removal was reduced because of an earlier presumption that "speedy processing" would result in less detention.

In the early 1980s, both the executive and Congress embraced the idea that procedural reform could lead to a substantive reduction in detention. The Reagan administration defended its use of long-term detention by blaming procedural delays in asylum processing. In a 1982 hearing, officials described the asylum process as "torturously slow" and stated that, "as a result, INS detention facilities [were] filled to overflowing." When they criticized detention, members of Congress adopted a similar presumption

63. Asylum and Inspections Reform, 121.

64. American Baptist Churches v. Thornburgh, 760 F. Supp. 796 (N.D. Cal. 1991).

65. Immigration and Naturalization Service's General Operations (1992), 35.

66. Hearing on United States as a Country of Mass First Asylum, before the Subcommittee on Immigration and Refugee Policy of the Committee on the Judiciary, United States Senate, 97th Cong. (1981), 14. 
that speedy processing would reduce confinement. In 1982, for example, the House Judiciary Committee introduced "speedy hearing" provisions to pending legislation, seeking to "obviate the possibility that aliens awaiting asylum determinations might be subject to lengthy detention." 67 Even the Editorial Board of the New York Times adopted this framework, recommending a "streamlined" hearing procedure in an editorial decrying the detention of Haitians (New York Times 1982).

However, the same speedy hearing provisions also attracted legislators who were concerned with so-called asylum abuse. During the anti-asylum fervor of the early 1990s, the Senate proposed asylum reform bills that would subject asylum seekers at the border to "summary exclusion" proceedings (Martin 1999, 162). The summary exclusion proposals, which had originated in the Reagan administration's immigration reform agenda, delegated certain asylum claims to INS officers, limited judicial review, and provided the basis for today's expedited removal regime (Schrag 2000, 44). These provisions may have been palatable to members of Congress who retained the association between shortened asylum procedures and reduced detention. In a 1995 hearing, for example, Senator Kennedy sought a cost comparison between detention and a "blanket summary exclusion system" at airports, wondering if summary exclusion would be a cheaper way to address "asylum abuse." 68

Expedited removal was connected to detention in another way as well. As lawmakers crafted the summary exclusion provisions in the 1990s, they borrowed mechanisms that the agency had used to ensure that people with legitimate asylum claims would be released from detention. The short-lived APSO screening program, discussed above, used a "credible fear" standard to determine which asylum seekers were likely to succeed in their claims and ensure that those individuals were released from detention (Coven 1993, 1; Office of the General Counsel 1996, 3; Schrag 2000, 34). When legislators considered expedited removal proposals in the 1990s, they used the "credible fear" standard from the detention release program. Indeed, in 1992, Representative Bill McCollum (R-FL) urged the adoption of this standard because the INS was "comfortable with it" and it had "worked in the detention area." 69

As the credible fear screening process migrated from the "detention area" to asylum reform, reformers soon forgot its ties to immediate release. While the standard was, in the words of INS Commissioner Chris Sale, originally used to ensure that someone who "appear[ed] to have a really good case, and does not need to be further hurt by the world by being in jail for a long time," it eventually became a tool to ensure the quick processing of asylum claims, without limiting detention. When Congress wrote summary exclusion provisions into the IIRIRA, it provided that noncitizens subject to expedited removal "shall be detained for further consideration of the application for asylum," even after establishing a credible fear of persecution. ${ }^{70}$ While the government had periodically released asylum seekers on bond after they passed credible fear proceedings, the attorney general reinterpreted this provision in 2019 in order to mandate that asylum

67. Committee on the Judiciary (1982), 57.

68. Immigration and Naturalization Service Oversight, 83.

69. Asylum and Inspections Reform, 124.

70. 8 U.S.C. $§ 1225(b)(1)(B)(i i)(1996)$. 
seekers who exhibited a credible fear of removal during expedited removal proceedings were ineligible for release. ${ }^{71}$

\section{CONCLUSION}

While 1981-96 were formative years in the making of mass immigration detention in the United States, this period has often been overlooked in the literature. Drawing upon both media coverage and a wealth of administrative and legislative records from this period, our analysis reveals a dynamic interplay between Congress and the executive during the formative years of immigration detention. Rather than being uniform, each branch's support for increasing immigration detention varied in important ways over time. A well-developed body of literature has demonstrated that the move to criminalize the noncitizen must be understood within a broader context of crime politics and mass incarceration more generally. As we demonstrate, the change in the perception of asylum seekers similarly cannot be understood without examining it alongside the legislative preoccupation with the criminal alien. Indeed, similar dynamics spurred Congress's frenzied attention to each type of noncitizen. Margaret Taylor $(2005,4)$ has shown that the public revelation of the INS's inability to remove criminal aliens, previously "something of an insider's secret," spurred lawmakers to act quickly. In the same way, the asylum crisis in the early 1990s and the resulting media preoccupation with the abuse of the asylum system caused Congress to act swiftly, resulting in laws allowing and sometimes mandating the detention of asylum seekers. As we demonstrate, careful analysis of these formative years is paramount to understanding how the United States developed and formalized the mass detention of immigrants. Similarly, an understanding of the institutional dynamics between Congress and the executive, and the ease with which the label of criminality was extended to asylum seekers, is essential to reimagining a different reality.

\section{REFERENCES}

Acer, Eleanor, and Olga Byrne. 2017. "How the Illegal Immigration Reform and Immigrant Responsibility of 1996 Has Undermined US Refugee Protection Obligations and Wasted Government Resources." Journal on Migration and Human Security 5, no. 2: 356-78.

Benhabib, Seyla. 2012. "Constructing the Self, Constructing the Other." Reset Dialogues on Civilization. https://www.resetdoc.org/story/constructing-the-self-constructing-the-other/.

Bibler Coutin, Susan 2005. "Contesting Criminality: Illegal Immigration and the Spatialization of Legality." Theoretical Criminology 9, no. 1: 5-33.

Boswell, Christina. 2007. "European Values and the Asylum Crisis." International Affairs 76, no. 3 : 537-57.

Bosworth, Mary, and Emma Kaufman. 2011. "Foreigners in a Carceral Age: Immigration and Imprisonment in the United States." Stanford Law and Policy Review 22, no. 2: 429-54.

Bosworth, Mary, and Mhairi Guild. 2008. "Governing through Migration Control: Security and Citizenship in Britain." British Journal of Criminology 48: 703-19.

Chacón, Jennifer. 2012. "Overcriminalizing Immigration." Journal of Criminal Law and Criminology 102, no. 3: 613-52. 
Chavez, Leo. 2001. Covering Immigration: Popular Images and the Politics of the Nation. Berkeley: University of California Press.

Chomsky, Daniel. 1999. "The Mechanisms of Management Control at the New York Times." Media, Culture Eु Society 21, no. 5: 579-99.

Christian Science Monitor. 1993. "Immigration Backlash." June 28.

Clines, Francis. 1993. "After Bombing, New Scrutiny for Holes in Immigration Net: In Aftermath of Terror of Trade Center Bombing, New Scrutiny for Holes in Immigration Net." New York Times, March 12.

Coven, Phyllis. 1993. "Legislative Package: Immigration Reforms." Memorandum to Rahm Emmanuel, October 4.

Diamond, Sara. 1996. "Right-Wing Politics and the Anti-Immigrant Cause." Social Justice 23, no. 3: $154-68$.

Dugger, Celia. 1997. "Dozens of Chinese from 1993 Voyage Still in Jail." New York Times, February 3.

Feinstein, Dianne. 1993. "Perspective on Illegal Immigration: We Can Get a Grip on Our Borders: The President Must Make Tough Enforcement a Policy Priority. The Burden on California Is Overwhelming." Los Angeles Times, June 16.

Fernandes, Julie. 1998. "Mandatory Detention." E-mail to Maria Eschaveste and Elena Kagan, September 21. https://clinton.presidentiallibraries.us/items/show/25178.

Foucault, Michael. 1977. Discipline and Punish: The Birth of a Prison. Allen Lane: London.

GAO (General Accounting Office). 1992. Immigration Control: Immigration Policies Affect INS Detention Efforts. Report no. GAO/GGD-92-85. Washington, DC: GAO.

García Hernández, César Cuauhtémoc. 2014. "Immigration Detention as Punishment." University of California Los Angeles Law Review 61: 1346-1414.

- 2019. Migrating to Prison: America's Obsession with Locking Up Immigrants. New York: New Press.

Garland, David. 2001. The Culture of Control: Crime and Social Order in Contemporary Society. Oxford: Clarendon Press.

- 2008. "On the Concept of Moral Panic." Crime, Media, Culture 4: 9-30.

Gibran Muhammad, Khalil. 2010. The Condemnation of Blackness: Race, Crime, and the Making of Modern Urban America. Cambridge, MA: Harvard University Press.

Gibson, William E. 1988. "2,000 Cubans Still in Prison." Miami Sun Sentinel, July 7.

Giuliani, Rudolph. 1992. "The Immigration Problem of the Reagan Administration." University of Miami Law Review 36: 807-818.

Gottschalk, Marie. 2014. "Democracy and the Carceral State in America." Annals of the American Academy of Political and Social Science 651: 288-95.

Harris, Casey T., and Jeff Gruenewald. 2020. "News Media Trends in the Framing of Immigration and Crime, 1990-2013." Social Problems 67, no. 3: 452-70.

Hamlin, Rebecca. 2012. "Illegal Refugees: Competing Policy Ideas and the Rise of the Regime of Deterrence in American Asylum Politics." Refugee Survey Quarterly 31, no. 2: 33-53.

. 2015. "Ideology, International Law, and the INS: The Development of American Asylum Politics 1948-Present." Polity 47, no. 3: 320-36.

Hedges, Michael. 1993. "Immigration Plan Seen as an Advance." Washington Times, July 28.

Hufker, Brian, and Gary Cavender. 1990. "From Freedom Flotilla to America's Burden: The Social Construction of the Mariel Immigrants." Sociological Quarterly 31, no. 2: 321-35.

Jefferis, Danielle. 2019. "Immigration Detention and Abolition." Harvard Law Review Blog, July 16. Johnson, Janis. 1982. "Bias Charged in Detention of Refugees from Haiti." Washington Post, March 16. Kaplowitz, Craig. 2018. "The Great Repudiator and Immigration Reform: Ronald Reagan and the Immigration Reform and Control Act of 1986." Journal of Policy History 30, no. 4: 635-56.

Khan, Jeffrey. 2019. Islands of Sovereignty: Haitian Migration and the Borders of Empire. Chicago: University of Chicago Press.

Kanstroom, Daniel. 2018. "Expedited Removal and Due Process: 'A Testing Crucible of Basic Principle' in the Time of Trump." Washington and Lee Law Review 75, no. 3: 1323-60. 
Lake, Anthony, Jack Quinn, Carole Rasco, and John Hilley. 1996. "Golden Venture Detainees." Memorandum for the President, August 5. https://clinton.presidentiallibraries.us/items/show/ 14715 .

Leiden, Warren. 1993. "Needed Now: Reform of the Asylum Process Arrival of Shiploads of Chinese Latest Immigration Concern." Baltimore Sun, June 13.

Lindskoog, Carl. 2018. Detain and Punish: Haitian Refugees and the Rise of the World's Largest Immigration Detention System. Gainesville: University Press of Florida.

Loescher, Gil, and John Scanlan. 1986. Calculated Kindness: Refugees and America's Half-Open Door, 1945-Present. New York: Free Press.

Loyd, Jenna, and Alison Mountz. 2018. Boats, Borders, and Basis: Race, the Cold War, and the Rise of Migration Detention in the United States. Oakland: University of California Press.

Malloch, Margaret, and Elizabeth Stanley. 2005. "The Detention of Asylum Seekers in the UK." Punishment $\mathcal{E}$ Society 7, no. 1: 53-71.

Macías-Rojas, Patrisia. 2018. "Immigration and the War on Crime: Law and Order Politics and the Illegal Immigration Reform and Immigrant Responsibility Act of 1996." Journal on Migration and Human Security 6, no. 1: 1-25.

Markus, Kent. 1995. "Views of the Department of Justice Concerning S. 269." Letter to Alan Simpson, May 23.

Martin, David. 1995. "Making Asylum Policy: The 1994 Reforms." Washington Law Review 70, no. 3: $725-55$.

- 1999. "Expedited Removal, Detention, and Due Process." In Defense of the Alien 22: 161-80.

McLeod, Allegra. 2012. "The U.S. Criminal-Immigration Convergence and Its Possible Undoing." American Criminal Law Review 49: 105-78.

McNary, Gene. 1992. "INS Memorandum re: Parole Project for Asylum-Seekers at Ports of Entry and in INS Detention." April 20.

Miller, Teresa. 2003. "Citizenship and Severity: Recent Immigration Reforms and the New Penology." Georgetown Immigration Law Journal 17, no. 4: 611-66.

Morrison, Patt. 1987. "Freedom the Hard Way: Angola Rebel Flees Marxist Torture, Lands in INS Detention." Los Angeles Times, July 15.

Muller, Thomas. 1997. "Nativism in the Mid-1990s: Why Now?" in Immigrants Out!: The New Nativism and the Anti-Immigrant Impulse in the United States, edited by Juan Perea, 105-18. New York: New York University Press.

Murakawa, Naomi. 2014. The First Civil Right. New York: Oxford University Press.

New York Times. 1982. "The Department of Detention." January 5. - 1986. "Cruel and Unusual Banishment." March 12.

1993a. "Fixing Immigration: New Waves of Refugees Buckle System As Cold War Policies Become Obsolete." June 8.

1993b. "The Golden Venture, Plus 100,000." June 9.

1993c. "The Refugee Panic Act of 1993." July 23.

Office of the General Counsel. 1996. "Asylum Pre-Screening Program Evaluation." Memorandum to Doris Meissner, Commissioner, INS, June 13.

Ostrow, Ronald. 1994. "Tight Reins Asked on Alien Marriages, Student Visas." Los Angeles Times, December 2.

Paik, A. Naomi. 2016. Rightlessness Testimony and Redress in U.S. Prison Camps since World War II. Chapel Hill: University of North Carolina Press.

Pistone, Michele. 1999. "Justice Delayed Is Justice Denied: A Proposal for Ending the Unnecessary Detention of Asylum Seekers." Harvard Human Rights Journal 12: 197-266.

Santa Ana, Otto. 2002. Brown Tide Rising. Austin: University of Texas Press.

Schmitt, Eric. 1996. "Provision in Terrorism Bill Cuts Rights of Illegal Aliens." New York Times, April 19.

Schmults, Edward. 1984. "Status of the Administration's Immigration Reform Legislation." Memorandum for Members of the Cabinet Council on Legal Policy, January 13.

Schrag, Philip G. 2000. A Well-Founded Fear: The Congressional Battle to Save Political Asylum in America. New York: Routledge. 
Schuck, Peter. 1992. "The Politics of Rapid Legal Change: Immigration Policy in the 1980s." Studies in American Political Development 6, no. 1: 37-92.

Schuck, Peter, and John Williams. 1999. "Removing Criminal Aliens: The Pitfalls and Promises of Federalism." Harvard Journal of Legislation and Public Policy 22, no. 2: 367-463.

Simon, Jonathan. 1998. "Refugees in a Carceral Age: The Rebirth of Immigration Prisons in the United States." Public Culture 10, no. 3: 577-607.

- 2007. Governing through Crime: How the War on Crime Transformed American Democracy and Created a Culture of Fear. New York: Oxford University Press.

Simon, Jonathan, and Malcolm Feeley. 1992. "The New Penology: Notes on the Emerging Strategy of Corrections and Its Implications." Criminology 30, no. 4: 449-74.

- 2003. "The Form and Limits of the New Penology." In Punishment and Social Control, edited by Thomas Blomberg and Stanley Cohen, 75-116. 2nd ed. New York: Walter de Gruyter.

Skelton, George. 1993. "Feinstein Takes Immigration Out of the Closet." Los Angeles Times, July 12. Stumpf, Juliet. 2014. "Civil Detention and Other Oxymorons." Queen's Law Journal 40, no. 1: 55-97. Stuntz, William. 1997. "The Uneasy Relationship between Criminal Procedure and Criminal Justice." Yale Law Journal 107: 1-76.

Task Force on Immigration and Refugee Policy. 1981. Report of the Task Force on Immigration and Refugee Policy. Memorandum for President Reagan, June 26.

Taylor, Margaret. 1997a. "Promoting Legal Representation: For Detained Aliens: Litigation and Administrative Reform." Connecticut Law Review 29: 1647-1711.

. 1997b. "Symbolic Detention." In Defense of the Alien 20: 153-59.

—. 2003. "Review, Detained: Immigration Laws and the Expanding I.N.S. Jail Complex." International Migration Review 3, no. 4: 1306-08.

—. 2005. "The Story of Demore v. Kim: Judicial Deference to Congressional Folly." In Immigration Stories, edited by David A. Martin and Peter H. Schuck, 343-76. New York: Foundation Press.

Tichenor, Daniel. 1994. "The Politics of Immigration Reform in the United States, 1981-1990." Polity 26, no. 3: 333-62.

Volsky, George. 1987. "Clamor Rises over Detention of Cuban Refugees by U.S.” New York Times, April 14.

Washington Post. 1987. "Stateless in Atlanta." April 2.

Webley, Lisa. 2010. "Qualitative Approaches to Empirical Legal Research.” In Oxford Handbook of Empirical Legal Research, edited by Peter Cane and Herbert Kritzer, 27-50. Oxford: Oxford University Press.

Welch, Michael. 1996. "The Immigration Crisis: Detention as an Emerging Mechanism of Social Control." Social Justice 23, no. 3: 169-84.

2002. Detained: Immigration Laws and the Expanding I.N.S. Jail Complex. Philadelphia: Temple University Press.

Welch, Michael, and Liza Schuster. 2005. "Detention of Asylum Seekers in the US, UK, France, German, and Italy: A Critical View of the Globalizing Culture of Control." Criminal Justice 5, no. 4: 331-55.

Yarnold, Barbara. 1990. "The Refugee Act of 1980 and the Depoliticization of Refugee/Asylum Admissions: An Example of Failed Policy Implementation.” American Politics Quarterly 18, no. 4: 527-36. 